Magyar Honvédség Egészségügyi Központ Védelem-egészségügyi Igazgatóság Pszichológiai és Egészségmagatartási Intézet, Egészségfejlesztési osztály

\title{
A munkahelyi egészségfejlesztési tevékenység rendszerének kialakulása és gyakorlata a Magyar Honvédségben
}

\section{Dr. Sótér Andrea alezredes, PhD}

Kulcsszavak: munkahelyi egészségfejlesztés, prevenciós programok, honvédség

\begin{abstract}
A NATO integráció követelménye a képesség alapú önkéntes haderő. A haderőt alkotó személyek hosszútávú alkalmazhatósága olyan egészségfejlesztési és preventív politika kialakítását igényli, amely képes elősegíteni a humán erőforrás legmagasabb szintü fizikai és mentális egészségének fejlesztését és védelmét. A cikk áttekintést nyújt a hadsereg egészségfejlesztési tevékenységének mérföldköveitől kezdve, a szabályozási és elméleti keretein át napjaink prevenciós programjainak bemutatásáig. Az áttekintést követően bemutatja a hon- és rendvédelmi szervezetek állományában végzett egészségfejlesztési tevékenység sajátosságait, számbavéve az aktualitásokat és jövőbeni célokat.
\end{abstract}

\begin{abstract}
Aktualitás
A katonai védelmi szektor hatékony müködése szempontjából a megelözésnek óriási szerepe van a személyi állomány indokolatlan és idő előtti elhasználódása, felesleges túlterhelése, a foglalkozási ártalmak kialakulása elleni fellépésben, de a helyes mentálhigiénés és megfelelő erőnléti állapot fenntartásában, a katonai feladatokhoz, a függelmi viszonyokhoz, a terhelések vállalásához való viszony helyes értékeinek ápolásában, a feladatok iránti motivációk kialakításában egyaránt. A megelőzés minden alkalmazott területen alapos helyzetismeretet, korszerü módszereket és kifinomult technikákat, valamint hozzáértő és tervszerü koordinációt igényel.
\end{abstract}

A hon- és rendvédelmi szerveknél szolgálatot teljesítők fokozott fizikai, pszichés igénybevétele az egészségi állapotot jelentősen befolyásoló tényező, amely az életkor elörehaladtával a szolgálatteljesítés képességének kérdését is elörevetíti. A 25 év szolgálat utáni, szolgálati nyugdíjba vonulás lehetőségének megszünésével [1] az idősebb, 50 év felettiek létszáma emelkedik az állomány körében. Az idősebb korral együtt járó egészségi problémák a fokozott terhelés miatt hatványozottan jelentkeznek, amely egyrészt speciális ellátási igényt támaszt az egészségügyi ellátórendszerrel szemben, másrészt a megbetegedés miatt szolgálatból kiesett munkavállaló helyettesítése humánerőforrás gazdálkodási problémaként is jelentkezik. 
A megbetegedéseknek azonban jelentős a gazdasági hatása is, az ún. betegségteher nemcsak az egyén szintjén manifesztálódik, mint jövedelem kiesés, egészségügyi kiadások, stb., hanem jelentős többlet kiadással jár a munkáltatónak is, mint a többletjárulék kifizetés, a helyettesítés miatti túlóra kiadások, stb. [2]. Azokban a szervezetekben, ahol a munkaerő speciális kiképzése hosszú időt, éveket vesz igénybe és viszonylag magas költséggel jár (pl. a repülő-hajózó állomány), a humán erőforrás értéke relatíve magasabb, ezáltal az egészséget támogató intézkedések megléte megkérdőjelezhetetlen. A munkaképesség megtartására, az egészségi állapot fenntartására fordított pénzösszegek jól megtérülő befektetésként értelmezhetőek, mivel a gyógyító ellátás költségéhez viszonyítva a prevenció költséghatékonysága az aktív, munkaképes korosztályra fordítva 5-10-szer magasabb. A munkavállaló egészségi állapotába, a munkahelyi prevenciós programokba történő befektetés a gazdasági szempontokon túl további pozitív hatásokkal is jár a szervezetben, erősödik a szervezet iránti lojalitás, emelkedik a termelékenység, javul a kommunikáció stb., amely szintén nem elhanyagolható, a hatékonyságot, s ezáltal a versenyképességet pozitívan befolyásoló tényező [3].

Bizonyos foglalkozások szimbolikus jelképpel rendelkeznek, mint például az egészségügyi dolgozók az önfeláldozó magatartással, a jogászok a „csavaros” gondolatmenettel, a pedagógusok az oktató-nevelö attitüddel. A katonának ilyen szimbolikus jelképe többek között az egészség, és az erről alkotott társadalmi összkép és megítélés. A katona-egészségügy alappillérei között, változó tevékenységi körrel ugyan, de a prevenció a kezdetektől fogva jelen volt.

\section{Az MH egészségfejlesztési tevékenységének mérföldkövei}

A Közegészségügyi és Járványügyi Állomás helyett egy új népegészségügyi szolgálat - az Állami Népegészségügyi és Tisztiorvosi Szolgálat - kialakításáról rendelkezett az 1991. évi XI. törvény. A jogalkotással a törvényhozó hatalom célja az volt, hogy a fertőző betegségek problémáit megoldani képes szolgálat mellett hozzon létre egy olyan szervezetet, mely a krónikus nem fertőző betegségeket is kezelni tudja, és amelynek jogszabályban deklarált feladatkörébe tartozik az egészségfejlesztési tevékenység is. A második nemzeti népegészségügyi program - amely a köztudatba „Kertai Program” néven került be - „A népegészségügy prioritásai az ezredfordulóig”, amelyet az országos tisztiföorvos vezetésével dolgoztak ki és „a hosszú távú egészségfejlesztési politika alapelveiről” szóló 1030/1994. (IV. 29.) Kormány Határozattal került elfogadásra. A jogszabálynak megfelelően, a Magyar Honvédségben az új szemléletü, a krónikus, nemfertőző megbetegedésekre fókuszáló tevékenység 1994-ben jelent meg, az akkori MH Közegészségügyi Intézetében[4]. Kezdetben - tekintettel arra, hogy akkor még megközelítőleg 40000 fő sorállományú katona teljesített szolgálatot - a legnagyobb kihívást a fiatal populáció - népegészségügyi szempontból is kiemelt problémaként számon tartott - kábítószer fogyasztása jelentette, ami a nemzetbiztonsági kockázaton túl jelentős kockázatot jelentett a fegyveres szolgálatot adó állományra nézve is. Az akkor végzett drog-epidemiológiai kutatások eredményei és a kábítószerek laboratóriumi szürővizsgálati gyakorlata alapján épült ki a ma is müködő komplex, többszintü kábítószer szürővizsgálati 
rendszer a hadseregben, melynek legitimitását a $\mathrm{MH}$ Drogprevenciós Bizottság megalakulása és azt követően a $\mathrm{MH}$ Drogprevenciós Stratégia kiadása jelentette 1999-ben [5].

$\mathrm{Az}$ „Egészségesebb laktanyákért program" volt az első, honvédségi hatáskörű munkahelyi közösségi egészségfejlesztési program, amely a legfontosabb népegészségügyi problémákra priorizálva (kábítószerfogyasztás, szexuális úton terjedő betegségek megelözése, lelki egészség megerősítése, stb.) a parancsnoki állomány bevonásával, a külső előadók imázsát kihasználva valósult meg [6]. A szakmai program 1995ben a MH Folyami Flottilánál debütált, és többszöri témabővítése után - szívérrendszeri-, anyagcsere-, mozgásszervi megbetegedések megelőzése - napjainkban az egészségügyi szűrővizsgálati eredmények alapján felállított alakulati rizikótérkép, a MH Egészségmegőrző Program néven működik. A sikeres pályázati tevékenység eredményeként lehetőség nyílt a nagyobb szabású és forrásigényü programok bevezetésére is. A szervezeti egészségfejlesztés nagy eredménye volt, hogy a 90-es évek végére - szinte minden alakulatot érintö - csapatorvosokból és egészségügyi szakdolgozókból álló egészségnevelői hálózat került kiépítésre. Az egészségügyi szakállomány több száz órás érzékenyítő és célirányos felkészítése után, valamint az oktatás módszertani fejlesztés hatására oktatói kézikönyvek, prevenciós szakkönyv sorozat állt rendelkezésre minden alakulatnál az állomány egységes egészségnevelési kiképzése érdekében [7].

„Az egészség a legerősebb fegyvered” című komplex egészségfejlesztő program kialakításában nagy szerepet játszott a United States Army Center for Health Promotion and Preventive Medicine
(CHPPM-EUR) landstuhli bázisán tett szakmai látogatás 1998-ban. A prevenciós tevékenységük alapelve, hogy a prevenciós feladatok a legmagasabb szintü harckészültségi állapot elérése és fenntartása köré és érdekében szerveződnek. Ezt szem elött tartva az egészségmegőrző program tematikájában szerepet kapott az egészséges táplálkozási szokások kialakítása, valamint a kulturált szabadidő eltöltési szokások kialakítása és a sport rekreáció témaköre is. Ebben az időszakban lépett hatályba a 12/1997. HM rendelet a hivatásos és szerzödéses katonák egészségi, pszichikai és fizikai alkalmasságáról, amely elöírta az állomány körében a kötelező éves fizikai állapotfelméréseket, ami az állomány részéről évekig jelentős ellenállásba ütközött. Ugyanakkor a figyelem fókuszát az egészséges életmód, a rendszeres testmozgás kialakításának irányába terelte.

A NATO csatlakozás után, a megnőtt műveleti szerepvállalás új feladatokra való felkészülést tett szükségessé. Megkezdődtek a szervezett, kiképzési tervbe illesztett felkészítő-, és az ún. reintegrációs tréningek a missziós szolgálatból visszatérők számára, melynek eredményeképpen 2000-ben a Mentálhigiénés osztály kialakításával szervezetszerü pszichológiai tevékenység jelent meg az egészségügyi szolgálati ágnál is [8]. Az időközben felhalmozott tudás, valamint a kutatási eredmények megosztására a társ fegyveres testületek részvételével több konferencián is ismertetésre kerültek a tapasztalatok (A segítő kapcsolatok szerepe a fegyveres szervezetek állományában; A drog ellen, a szabad életért; 2003. és 2004. évben). A hadsereg kiképzési rendszerétől eltérő, új oktatás módszertani szemlélet (kis csoportos foglalkozások, kortárs oktatás), a további pályázati források által megteremtett anyagi fede- 
zet lehetőséget adott olyan akkreditált továbbképzések, tréningek megtartására az egészségügyi szakállomány részére, mely a probléma iránti érzékenységet, az egészségtudatos szemléletformálást széles körben megalapozta, ill. továbbfejlesztette. A katonaegészségügy egyik alappillére, a preventív medicina szakterülete bővült a $\mathrm{MH}$ egészségfejlesztési föszakorvosi beosztás kialakításával, amely a felsővezetés szintjén is erősítette a csapategészségügytől a központi tagozatig átfogó egységes szemléletü egészségfejlesztési tevékenységet. Az egészségfejlesztési munka színvonalát jelzi, hogy a korábban már részletezett „Egészséges Nemzetért Népegészségügyi Program 2001-2010" végrehajtása érdekében létrehozott Népegészségügyi Tárcaközi Bizottság munkájában a honvédelmi tárca képviseletét a MH egészségfejlesztési föszakorvosa látta el.

2009-ben a katonai felsőoktatásban, a Zrínyi Miklós Nemzetvédelmi Egyetem Védelemegészségügyi Intézet megalapításával, és azon belül az Alkalmazott Egészségtudományi Tanszék kialakításával lehetőség nyílt a katonai felsőoktatásba is integrálni az egészségfejlesztési tudományterületet. Annak ellenére, hogy az Intézet által több szakindítási kérelmet jóváhagyott a Magyar Akkreditációs Bizottság, az egyetemet is elérő felsőoktatási reform során jogutód nélkül megszünt az Intézet, és a képzések már nem kerülhettek bevezetésre.

A szakmai fejlődés következő szintje - amely a katonaegészségügyi szakterület folyamatos átszervezéséből adódó feladatátadások következménye is volt az egészségügyi monitorozó rendszerek (hazai és missziós betegforgalmi adatok, éves egészségügyi szűrővizsgálati adatok) egy szervezeti elemhez történő rendelése volt. Ennek nagy előnye volt, hogy
- a csökkenő létszám mellett - nem volt szükség önálló kutatási adatgyüjtésekre, a meglévő monitorozó rendszerek célzott bővítése (egészségügyi szűrővizsgálati adatlap átdolgozása prevenciós adatlappá) kielégítette az állomány egészségi állapotát tovább differenciáló adatigényt. $\mathrm{Az}$ éves egészségügyi szűrővizsgálat elektronikus adatszolgáltatásának kiépülésével, valamint a hazai és missziós betegforgalmi adatok egységes adatbázisba rendezésével és epidemiológiai elemzésével számos új kutatási eredmény támogatta a felső vezetői döntés előkészítést is. Az adatok évről-évre azonos szempontú elemzése és értékelése lehetővé tette az egészségi állapotbeli változások trendjének vizsgálatát is, amely tudományosan megalapozott ún. evidence based prevenciós programok (komplex életmódváltást megcélzó prevenciós modell program, misszióból visszaérkező katonák 14 napos regenerációs programja, stb.) kialakítását tette lehetővé [9]. Elkészült a Magyar Honvédség első (2007) és második (2012) egészségrizikó térképe, mely az alakulatok közötti egészségi állapotbeli különbségeket feltárva hozzájárult a MH Egészségmegőrző Prémium Program, mint célzott prevenciós beavatkozás tervezéséhez [10].

\section{Az egészségfejlesztési tevékenység szabályozása}

$\mathrm{Az}$ egészségfejlesztési tevékenység szabályozása a 21/2003. (VI. 24.) „a Magyar Honvédség feladatával kapcsolatos közegészségügyi-járványügyi követelményekröl, azok ellátásának, valamint az Állami Népegészségügyi és Tisztiorvosi Szolgálattal való együttmüködésének rendjéröl" szóló HM-ESzCsM együttes rendelet 6 . $\$$ -ban foglalt Egészségfejlesztési feladatok meghatározása alapján valósul meg. Az 
1/2009 (I. 30.) a Magyar Honvédségre, illetve a katonai nemzetbiztonsági szolgálatokra vonatkozó eltérő munkavédelmi követelményekröl, eljárási szabályokról szóló $\mathrm{HM}$ rendelet $35 . \$ \mathrm{~b}$ ) pontja alapján, az MH egészségügyi feladatokat ellátó központi szerve, folyamatosan figyelemmel kíséri, elemzi és értékeli a személyi állomány egészségi állapotát veszélyeztető fizikai, kémiai, biológiai, pszichoszociális és környezeti természetü kockázati tényezőket, valamint azok egészségi állapotra gyakorolt hatásait, intézkedik, illetve javaslatot tesz a veszélyeztető tényezők megszüntetésére, az egészségkárosító kockázatok csökkentésére. Az egészségi állapot rendszeres időközönként végzett monitorozása a 10/2015. (VII.30.) a katonai szolgálatra való egészségi, pszichikai, fizikai alkalmasságról és a felülvizsgálati eljárásról szóló HM rendeletben került egységes szabályozásra. A HM rendelet egyik fő célja, a több célból végzett egészségügyi szürővizsgálati rendszer racionalizálása, átalakult a korábban évente változó korcsoportonkénti, egyben hazai beosztásra katonai alkalmasságra is minősítő alkalmasságvizsgáló eljárás. Ennek keretében kerül felvételre a prevenciós adatlap, amely nemzetközi skálákkal kiegészítve alkalmas az egyes itemek önálló értékelésére (pl. OSAS - Obstruktív alvási apnoae, Fragerström - dohányzás függőség, stb.) és az életmód feltérképezésére. A meghatározott időszakonként felvett kérdőív adatai által alkalmas az egyéni változások követésére is. A 253/2008. (HK 7.) MH HEK intézkedés a Magyar Honvédség külföldön szolgálatot teljesitö személyi állománya betegforgalmi adatainak jelentési rendjéröl (EPIHUN) határozza meg az ún. surveillance jelentési rendszer működtetését.

A Magyar Honvédségben végzett drogprevenciós tevékenység a 40/2012.
(VI. 15.) HM utasítás a MH Drogprevenciós Bizottságáról és a 26/2008. (HK 7.) HM utasítás a Magyar Honvédség személyi állománya kábitószer hatása alatti állapotának, illetve kábitószer fogyasztásának vagy tartásának ellenörzéséröl, valamint a 167/2009. (HK 5.) MH HEK parancsnoki intézkedés a Magyar Honvédség személyi állománya kábitószer hatása alatti állapotának, illetve kábitószer fogyasztásának vagy tartásának ellenörzésével kapcsolatos feladatok végrehajtásáról szóló jogszabályok által valósul meg.

$\mathrm{Az} \mathrm{MH}$ Egészségügyi doktrina szerint, „egészségügyi szempontból a haderővédelem nem más, mint a harcképesség megőrzése úgy, hogy a harcoló katona egészséges, hadrafogható és alkalmazható legyen meghatározott időben és helyszínen" [11]. A fokozott egészségtudatos szemlélet és magatartás kialakításának kiemelt jelentősége van a misszióba készülő állomány felkészítése alkalmával a nem harci eredetü sérülések, betegségek (DNBI, diseases and non battle injuries) megelőzésében.

A MH Szolgálati Szabályzat (Ált. 23.) szerint az „egységparancsnok kísérje figyelemmel az alárendeltek egészségi, pszichikai és fizikai állapotát, gondoskodjék a számukra előírt munkakörülményekről és az egészséges életmódra való nevelésükről, óvja egészségüket és testi épségüket”; továbbá „az egység egészségügyi főnök (egészségügyi központ parancsnoka) szervezze és végezze az egészségvédelmi, egészséges életmódra nevelési, egészségfejlesztési és drogmegelőzési felvilágosító munkát."

$\mathrm{Az}$ állomány körében elöforduló elhízás kialakulásának megelőzésére, ill. a túlsúlyos, vagy elhízott állomány testsúlyának csökkentésére a Honvéd Testalkati Program került bevezetésre a 10/2015. 
(VII. 30.) a katonai szolgálatra való egészségi, pszichikai és fizikai alkalmasságról, valamint a felülvizsgálati eljárásról szóló HM rendelet $12 \$$-a alapján. Eszerint az egészségi alkalmasság vizsgálat során mérni kell a testtömeget, testmagasságot és a testzsír százalékot (az MH-ban egységesen az OMRON BF 511 készülékkel). Amennyiben a honvéd túllépi a 3. melléklet $\mathrm{N}$ ), O) és $\mathrm{P}$ ) pontjában meghatározott testalkati mutató értéke(ke)t, fel kell hívni a figyelmét a Honvéd Testalkati Programban való részvétel lehetőségére. A Honvéd Testalkati Program kidolgozása, a vizsgálóeljárások és a ráépülő tanácsadás folyamatos szakmai fejlesztése az $\mathrm{MH}$ Egészségügyi Központ Egészségfejlesztési osztály szakemberei által valósult meg [12]. A program hiánypótló szerepet tölt be az érintett egyes klinikai praxisok között, népszerűségét mutatja, hogy már a kezdetektől más hon és rendvédelmi szervezetek tagjai is részt vesznek - az egyébként nem OEP által finanszírozott - egy éves testsúlyrehabilitációs programban.

\section{Az egészségfejlesztési tevékenység elméleti alapjai}

Az egészségfejlesztés elmélete magának az egészség fogalmának (biomedikális, bio-pszicho-szociális, percepciós, stb.) a változásával párhuzamosan fejlődött. $\mathrm{Az}$ Egészségügyi Világszervezet korai (1946) egészség definiciója szerint az egészség a testi, lelki és szociálisjóllét állapota, vagyis több, mint a betegség hiánya. Caplan ekkor fogalmazta meg elöször a primer, a szekunder és a tercier prevenciós szinteket és a hozzájuk tartozó beavatkozások körét. Az egészségfogalom alakulására számos elmélet hatott, pl. Grossman (1972) az egészségtőke elmélete, vagy Lalonde 1974-es egész- ség mező elmélete, miszerint az az életmód 43\%-ban, az egészségügyi ellátás színvonala 15\%-ban „felelős” az egyén egészségéért, feltárta a környezeti és genetikai tényezők jelentőségét az egészségi állapot megtartásában. Az Egészségügyi Világszervezet egészségfejlesztési alapdokumentuma, az Ottawai Charta 1986-ban deklarálta, hogy az egészségfejlesztés egy olyan folyamat, amely képessé teszi az egyéneket és közösségeket az egészségük feletti kontrollra, azaz életmódjuk és környezetük befolyásolására, ami több az egészséget veszélyeztető kockázati tényezők elkerülésénél [13]. $\mathrm{Az}$ egészség társadalmi modelljében a társadalom valamennyi szektorának és szereplőjének felelősségét meghatározta, az erőforrásokra és a közösségekre fókuszálva. Antonovsky salutogenesis elmélete (1987) szintén jelentős hatással bírt az egészségszemlélet formálódására, melynek alapja az egészség, mint egyensúlyi állapot; és a koherencia-érzet a kulcs ennek megtartásában [14]. A gazdaságilag fejlett országokban napjainkban zajló IV. epidemiológiai paradigmaváltás jellemzője, hogy az idősödő társadalmakban a krónikus betegségek időtartama és kezelési ideje kitolódik - akár évtizedekig is eltarthat - ami szintén jelentös hatással van az egészség fogalmának bővülésére, mint a méltányosság, társadalmi igazságosság, emberi jogok, esélyegyenlőség alapelveinek beépülésével [15]. Az ezredfordulóra a túlzott medikalizáció következményeinek megelőzésére megjelent a kvaterner (negyedleges) prevenció fogalma. Az egészségpszichológiai tudományág fejlődése az egészségfogalom további bővülését hozta. A rendszerszemléletü medicina térhódítása, az egyéni életmódorvoslás helyett már az életvezetési kompetenciafejlesztésre fókuszáló irányzatok váltak napjaink meg- 
határozó egészségfejlesztési irányzataivá $[16,17]$.

Ahogyan korábban említettem, az Ottawai Chartában jelent meg a színterekben való gondolkodás: „a munka és a szabadidő az egészség forrásai kell, hogy legyenek az emberek számára. (...) Az egészségfejlesztés olyan élet- és munkakörülményeket hoz létre, amelyek biztonságosak, ösztönzőek, kielégítőek és élvezetesek." A Munkahelyi Egészségfejlesztés Európai Hálózatának Luxemburgi Deklarációja szerint a munkahelyi egészségfejlesztés a munkaadók, a munkavállalók és a társadalom valamennyi olyan együttes tevékenységét jelenti, amely a munkahelyi egészség és jól-lét javítására irányul. A cél eléréséhez szükséges lépések és eszközök a munkaszervezet javítása, a dolgozói részvétel biztosítása és a személyi kompetencia fejlesztése. Az Egészségügyi Világszervezet (WHO) 2007-ben megalkotott ábráján a munkahelyi egészségfejlesztés folyamata (felmérés, tervezés, megvalósítás, értékelés), valamint szereplői és feltételei (biztonságos munkavégzés, vezetői elkötelezettség, egészségtudatos humánpolitika, megfelelő kockázatbecslés, foglalkozás-egészségügyi ellátás, munkavállalók bevonása) együttesen láthatóak (1. ábra). Ezen elöfeltételek hiányában sikeres munkahelyi egészségfejlesztési tevékenység nem valósulhat meg [18]. A szervezeti egészségfejlesztés egyrészt irányulhat az egyén (munkavállaló) viselkedésének a megváltoztatására (viselkedés orientált stratégia: pl. dohányzás leszoktatást támogató csoportok, testösszetétel mérés, stb.), másrészt magára a munkáltatóra, amely olyan munkakörnyezetet alakít ki (környezet orientált stratégia: pl. dohányzási tilalom, korszerü étlap a munkahelyi étkezdében, kondicionáló terem hasz- nálatának biztosítása), amely támogatja az egészséges életmódot. A civil munkáltatóknál ez a feladat a humánerőforrás gazdálkodás része, egyenlöre fóként a multinacionális cégeknél vállalati wellness menedzsereket, ill. egészségmenedzsereket alkalmaznak a vállalati egészségtervek elkészítésére és a megvalósításban, fenntartásban résztvevők koordinálására. A profitorientált munkáltatók alapvetően érdekeltek abban, hogy munkavállalóik a lehető legkevesebb egészségdeficittel rendelkezzenek, mivel a dolgozók egészségére fordított összegek befektetésként értelmezendők. Költséghatékonyságuk középtávon (1-3 év) kimutathatóan megtérül, így hosszú távú befektetésnek tekinthetők a dolgozók egészégére költött kiadások.

\section{A munkahelyi egészségfejlesztési tevékenység gyakorlata a hadseregben}

$\mathrm{Az}$ egészségfejlesztési tevékenység a népegészségügyi ciklus folyamatának lépései szerint jelenik meg. Először a helyzetelemzés fázisában történik meg az állapot leírás, amely statisztikai adatokat tartalmaz az állomány egészségi állapotára, egészségmagatartására vonatkozóan. Ezen adatok a korábban említett betegforgalmi, ill. szűrővizsgálati adatokból vagy célzott kutatásból nyerhető, mely adatbázisok karbantartása 2007 óta folyamatos. A következő lépés a szükségletek azonosítása és rangsorolása, amely az egészségterv problématérképét alkotja (lásd korábban, $\mathrm{MH}$ alakulati egészségrizikó térképek) $[10,19]$. A priorizálást a morbiditási (megbetegedési arányszám) mutató, ezen belül az incidencia (az adott betegség új eseteinek száma egy adott időtartamban) és a prevalencia 


\section{A WHO egészséges munkahely modellje (2007)}

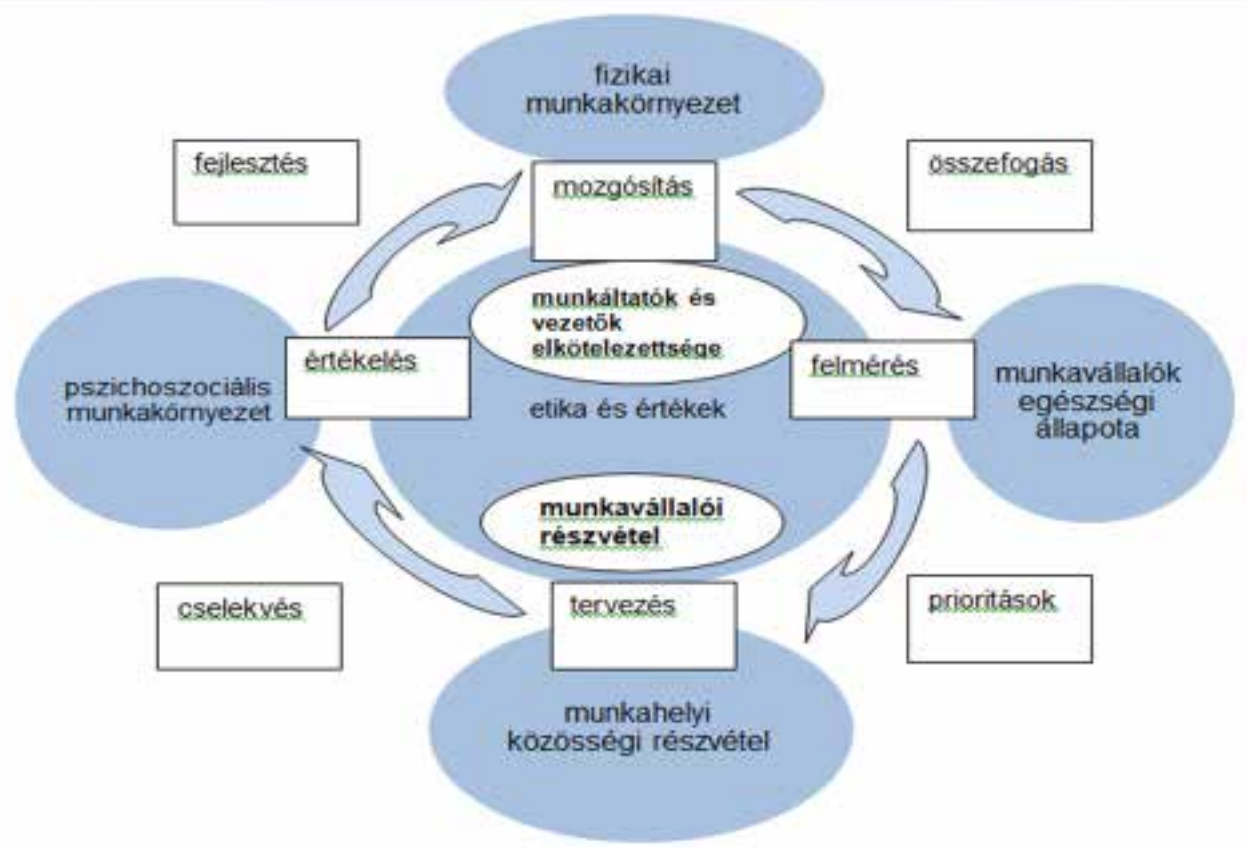

1. ábra. Az Egészségügyi Világszervezet egészséges munkahely modellje

(Forrás: WHO, 2007)

(egy adott betegségben szenvedők összlétszáma) arányszámai határozzák meg. Azokra a népegészségügyi szempontból is kiemelt problémákra fókuszált, amelyek a leggyakrabban fordulnak elö az állomány körében (pl. szív-, érrendszeri megbetegedések, különös tekintettel a magas vérnyomás betegségre, vagy az emésztőszervi-, anyagcsere betegségek, mint a zsír anyagcsere zavara stb.).

A katonai szolgálatból adódó speciális megbetegedési mintázatok mellett a programok tervezésében szerepet kap az alakulati szintről érkező igények támogatása is (új típusú pszichoaktív anyagok fogyasztása, a multikauzális szürővizsgálatok: kiemelten a vércseppből végzett prosztata-antigén vizsgálat, PSA). A harmadik lépés az egészségfejlesztési programok tervezése, szervezése és kivitelezése.
A csapategészségügyi szolgálatot elérö kritikus létszám miatt gyakorlatilag az Egészségfejlesztési osztály fokozatosan átvette az intervenciós feladatok végrehajtását az alakulatoknál. A prevenciós programok éves tervezése során az alakulati igények figyelembevételével - a HM éves munkaterve alapján az ágazati katonai rendezvényekre is figyelemmel - az osztály kapacitásának, lehetőségeinek figyelembevételével összeállított éves cselekvési terv alapján kerül végrehajtásra a prevenciós tevékenység. A folyamat utolsó lépése az értékelés és a hatékonyságelemzés - a minőségbiztosítási kérdőívek eredményei alapján, az előre meghatározott indikátorok szerint. Az alakulatok számára a saját egészségtervük elkészítéséhez 2014-ben módszertani segédletet készítettünk és adtunk $\mathrm{ki}$, amely bemutatja az egészségtervek 
készítésének és megvalósításának lépéseit, ezzel is támogatva a helyi prevenciós kezdeményezéseket [20]. A Magyar Honvédségben jelenleg elérhető prevenciós programokat az intervenció szintje szerinti felsorolásban az alábbi táblázatban foglaltuk össze (1. táblázat).

A korábban említett $\mathrm{MH}$ Egészségmegőrző Program legnépszerübb témái 2016-ban az öregedéssel járó fizikai változások és az optimalizálás lehetőségei, a stresszhez társuló pszichoszomatikus megbetegedések megelőzése, valamint az étrendkiegészítők használatát bemutató témakörök voltak. Az előadások 13 alakulat éves kiképzési tervében szerepeltek. A minőségbiztosítás keretében felvett hallgatói elégedettségi vizsgálat eredményei alapján a résztvevők kiemelkedőnek ítélték meg az előadók felkészültségét és jártasságát a témákban, valamint minden esetben kaptak új információt is, amely beépíthető a mindennapi életükbe, valamint a szolgálatteljesítésükre is pozitív hatással bír. A már valamilyen egészségdeficittel rendelkezők részére az ún. indikált intervenciónak minősülő $\mathrm{MH}$ Egészségmegőrző Prémium Program keretében 2016-ban közel 300 fö multikauzális szürővizsgálatát végeztük el a honvédségi alakulatoknál. Intimitásuk miatt ezek az egyéni kockázatbecslés alapján végzett egyéni életmód tanácsadással egybekötött prevenciós beavatkozások egyre népszerübbek az állomány körében, mivel pl. a Vicardio ún. szívstressz vizsgálat csak ebben a szürővizsgálati

I. táblázat. A honvédség prevenciós programjainak áttekintése

(Szerk. Sótér, 2015.)

\begin{tabular}{|c|c|c|c|c|}
\hline $\begin{array}{l}\text { Prevenció } \\
\text { szintje }\end{array}$ & $\begin{array}{l}\text { Akció/ } \\
\text { Intervenció }\end{array}$ & Cél & Módszer & Helyszín \\
\hline $\begin{array}{l}\text { Primordiális } \\
\text { (indirekt) }\end{array}$ & $\begin{array}{l}\text { családi-, sport-, } \\
\text { alakulati napok, } \\
\text { fesztivál, } \\
\text { szemle }\end{array}$ & $\begin{array}{l}\text { szervezet fej- } \\
\text { lesztés (kom- } \\
\text { munikáció, } \\
\text { csapatmunka, } \\
\text { együttmüködés) }\end{array}$ & $\begin{array}{l}\text { szabadidős, rekreá- } \\
\text { ciós tevékenység }\end{array}$ & $\begin{array}{l}\text { honvédségi lak- } \\
\text { tanyák, közössé- } \\
\text { gi színterek }\end{array}$ \\
\hline $\begin{array}{l}\text { Univerzális } \\
\text { (általános) }\end{array}$ & $\begin{array}{l}\text { MH Egészség- } \\
\text { megőrző Prog- } \\
\text { ram (12 téma- } \\
\text { körben) }\end{array}$ & $\begin{array}{l}\text { kognitív infor- } \\
\text { máció átadás, fi- } \\
\text { gyelemfelkeltés }\end{array}$ & $\begin{array}{l}\text { frontális előadás, } \\
\text { kiscsoportos meg- } \\
\text { beszélés, plakátki- } \\
\text { állítás }\end{array}$ & $\begin{array}{l}\text { honvédségi lak- } \\
\text { tanyák }\end{array}$ \\
\hline $\begin{array}{l}\text { Javalott } \\
\text { (indikált) }\end{array}$ & $\begin{array}{l}\text { MH Egészség- } \\
\text { megőrző Prémi- } \\
\text { um Program, } \\
\text { kampányok }\end{array}$ & $\begin{array}{l}\text { premorbid álla- } \\
\text { pot kiszürése }\end{array}$ & $\begin{array}{l}\text { multikauzális szü- } \\
\text { rés: vérnyomás, } \\
\text { vércukor, PSA, ko- } \\
\text { leszterin szint mé- } \\
\text { rés, testösszetétel, } \\
\text { szívstressz mérés }\end{array}$ & $\begin{array}{l}\text { honvédségi lak- } \\
\text { tanyák, rekreá- } \\
\text { ciós központok }\end{array}$ \\
\hline $\begin{array}{l}\text { Célzott } \\
\text { (szelektív) }\end{array}$ & $\begin{array}{l}\text { Honvéd Testal- } \\
\text { kati Program, } \\
\text { stressz-kezelés } \\
\text { fejlesztés, do- } \\
\text { hányzás leszok- } \\
\text { tatás támogatása }\end{array}$ & $\begin{array}{l}\text { viselkedés válto- } \\
\text { zás támogatása }\end{array}$ & $\begin{array}{l}\text { személyre sza- } \\
\text { bott tanácsadás, } \\
\text { coaching, tréning }\end{array}$ & $\begin{array}{l}\text { MH EK } \\
\text { Életmód- } \\
\text { tanácsadó Iroda }\end{array}$ \\
\hline
\end{tabular}


programban érhető el. A vizsgálatokon kiszürt, magas kockázati státuszú személyeket minden esetben az egyéni tanácsadás mellett szakorvosi kivizsgálása irányítottunk. A prevenciós programok harmadik szintje a már kifejezetten tünettel és panasszal rendelkezők részére a szelektív, célzott beavatkozás, amikor már csak az adott egészségproblémára fókuszálva történik az intervenció. Jelenleg a 2015-ben indított és egyben a legsikeresebb program a testsúlyfelesleggel rendelkezők számára a Honvéd Testalkati Program, de évről-évre emelkedik a Williams Életkészség (WÉK) programban résztvevők száma is. A kommunikációs készség fejlesztető és stressz kezelést fejlesztő program hatékonyságvizsgálati eredményei alapján a 3 hónapos követéses vizsgálat végére is szignifikánsan megmarad a munkahelyi stressz szint csökkenése [21]. A WÉK tréningeket a Selye János Magatartástudományi Társaság által kiképzett facilitátorok vezetik, melynek népszerüségét az is mutatja, hogy a munkaidőn kívül meghirdetett csoportokba is túljelentkezés van.

A fentiekből is látható, hogy a prevenciós programok során az egészségtudományok szinte valamennyi területe képviselteti magát az egészségfejlesztési tevékenység multidiszciplinaritásából adódóan. Az Egészségfejlesztési osztály állománya magasan kvalifikált szakemberekből áll: népegészségügyi felügyelő és szakértő, egészségtan-, testnevelő tanár, egészségpszichológus, egyetemi diplomás ápoló, biostatisztikus, dietetikus, egészségfejlesztő, táplálkozástudományi szakértő, személyi edző, tréner, coach. Természetesen a tudományos tevékenység is kiemelt szerepet kap, jelenleg 2 fö rendelkezik $\mathrm{PhD}$ fokozattal és 3 fö a doktori tanulmányait végzi. Mindhárom doktorandusz kutatási területe az egészségfej- lesztési tevékenység aktuális kihívásaira fókuszál: a mentális állóképesség szerepe az egészségmagatartás változásában, a motiváció szerepe az életmódváltásban és az egészségmagatartási mutatók hatása az egészségi állapotra.

Az aktív egészségfejlesztési munka mellett természetesen az alakulatoknál szolgáló egészségügyi szakállomány képzésére is nagy hangsúlyt fektetünk, évente szervezünk akkreditált tanfolyamokat a preventív szemlélet "éberségének” fenntartása érdekében.

A hadsereg állománya, összetétele folyamatosan változik, egyrészt a fluktuáció, másrészt a munkaéletkor meghosszabbodása miatt. Ezért a jövő egészségfejlesztési tevékenységében az új belépők részére indokolt fent tartani az ún. alapprogramok folyamatos elérhetőségét ( $\mathrm{MH}$ Egészségmegőrző Program, alakulati egészségnapok szakmai támogatása), az egészségdeficittel rendelkező speciális igényü csoportok részére meghirdetett programokat (MH Egészségmegőrző Prémium Program, Honvéd Testalkati Program, stressz-kezelő tréningek). Másrészt a munkaéletkor meghosszabbodása miatt az MH Életmódtanácsadó Iroda profilbővítésének keretében a további egyéni és csoportos készségfejlesztő foglalkozások körét is (időgazdálkodás, senior hatékonyság fejlesztés, életmódváltó tréningek, egészségmenedzsment) is bővíteni tervezzük. Hiánypótló program szerepét tölthetné be az életmódváltó táborok beindítása, melyek intenzív formában kihasználva a meglévő infrastruktúrát (Kiképzési, oktatási és regeneráló központok) egyhetes elméleti és gyakorlati edukáció keretében támogathatnák az életmódváltást fontolgatókat.

$\mathrm{Az}$ egyéni viselkedés változtatás támogatásán túl elengedhetetlen a szervezeti egészséget támogató vezetés el- 
kötelezödése, az önálló prevencióra fordítható költségvetés biztosítása, valamint a szakember hálózat ismételt kiépítése, amit a prevenciós tiszti beosztások kialakításával javasolunk beintegrálni a vezetés rendszerébe.

\section{A hon és rendvédelmi szervek munkahelyi egészségfejlesztésének sajátosságai}

Egészségfejlesztési tevékenységet azokon a helyszíneken vagy közösségekben célszerü elsősorban végezni, ahol szervezett struktúra és infrastruktúra áll rendelkezésre. A munkahelyi egészségfejlesztési tevékenység a színtér programok közé sorolt, mivel állandó munkavállalói körrel és a hon- és rendvédelmi szervek bürokratikus sajátosságából adódó hierarchikus struktúrával rendelkezik. Ezekben a jól átlátható feladat és felelősségi körü szervezetekben is - amilyen a hon- és rendvédelmi szervezetek - az egészségfejlesztési tevékenység megvalósítása könynyebb, mint egy ideiglenes szerveződésü, csak egy közös tulajdonsággal (egészségdeficittel) rendelkező csoportban. A sikeres egészségfejlesztési tevékenység másik elöre jelzője, hogy ezek a szervezetek rendelkeznek önálló és saját medikai adatgyüjtési rendszerekkel (alkalmasság-vizsgálati, éves szürővizsgálati, betegfogalmi), tehát az állapotleíráshoz szükséges adatok folyamatosan rendelkezésre állnak. A hon- és rendvédelmi szervezeteknél végzett egészségfejlesztési tevékenység során szintén előnyként dedikálható, hogy a „hivatásból” adódóan a hosszabb szolgálati időtartam alatt - amely évtizedeket is felölelhet - hosszú idő áll rendelkezésre a tervezett egészségfejlesztési beavatkozásokra, a hatékonyság mérésére. Előnyként értelmezhető továbbá, hogy a munkavállaló szigorú és rendszeres alkalmasság vizsgálaton vesz részt, pozitívan szelektálódik, vagyis magasabb egészségnívójú egyének kerülnek be, ami a kedvezőbb egészségmutatókra tervezett prevenciós stratégia és cselekvési terv hatékonyságát garantálhatja. $\mathrm{Az}$ életkortól függő periodicitással végzett egészségügyi minősités, ill. az időszakos szűrővizsgálatok során lehetőség van a megbetegedések korai felismerésre és ezzel a mielőbbi gyógyítására [21], ami a gyógyulási esélyt javítja.

A hon- és rendvédelmi szervezetek állományában végzett egészségfejlesztési tevékenység túlmutat a gazdasági érdeken, mivel e szervezetek működésének feltétele a harc-, a szolgálatképesség fenntartása, ami túlmutat az egyéni érdekeken. Az itt szolgálók egészségének megtartása és fenntartása e szervezetek alapérdeke.

\section{Összegzés}

Összegezve elmondhatjuk, hogy az egészségvédelem - többek között az egységes vezetői koncepciónak köszönhetően - hosszú, átszervezési ciklusokon átívelő múltra tekint vissza a $\mathrm{MH}$ egészségügyi ellátórendszerén belül, a több évtizedes munka eredményeképpen:

- jelentős mennyiségü információt és tudást halmozott fel az állomány egészségi állapotával és egészségmagatartásával kapcsolatban;

- katonai és civil-katonai rendezvényeken történő rendszeres megjelenésével ismertté és elismertté vált a felső vezetés és az állomány körében;

- a nemzeti népegészségügyi szervezetek, intézmények munkájában aktív szerepet vállalt;

- oktatási, továbbképzési és kiképzési tevékenységével hozzájárult a (szak) állomány ismereteinek bővítéséhez;

- tudományos munkásságának (kon- 
ferencia előadások, publikációk) köszönhetően bekapcsolódott a hazai tudományos szakmai életbe.

A honvédségen belüli preventív medicina arra törekszik, hogy tagjai egészségét ne csak megtartsa, helyreállítsa, hanem szervezetüket edzetté, a terheléseket, megpróbáltatásokat elviselövé, a betegségekkel szemben ellenállóvá tegye. A Magyar Honvédség jelenleg tagolt egészségügyi szolgálata részben képes ezen feladatok elvégzésére. A rendszerrel szemben támasztott egyre fokozódó követelmények azonban indokolttá teszik a jelenlegi rendszer újragondolását, a feladatok - struktúra tekintetében a hatékonyabb és minőségi kritériumoknak megfelelő munkavégzés érdekében. Egyre sürgetőbb feladatként jelentkezik a közösségi egészségfejlesztő hálózat újraszervezése, valamint az egészségfejlesztést érintő új szabályozások kidolgozása. Az egészségfejlesztés - a személyi állomány harcképességének megörzésében betöltött súlyát és jelentőségét tekintve - nem tekinthető az Magyar Honvédség Egészségügyi Központ „belügyének”, a hálózatosodás (network) irányában kell a rendszert fejleszteni oly módon, hogy a fejlödés motorja, az egészségfejlesztés koordinátora, szervezője, szakmai felügyelője az MH EK legyen.

\section{Irodalom}

[1] 2011. évi CLXVII. törvény A korhatár elötti öregségi nyugdíjak megszüntetéséről, a korhatár előtti ellátásról és a szolgálati járandóságról

[2] Kaló Z., Inotai A., Lukovics F.: Egészség-gazdaságtani fogalomtár II. Az egészségügy piacának, finanszírozásának és beruházásának gazdasági elemzése, Professional Publishing Hungary Kft., Budapest, 2009.
[3] Szilágyi Zsuzsanna: Egészségmegőrzés, egészségvédelem, egészségnevelés a Magyar Honvédségnél; Nederlands Militair Geneeskundig Tijdschriff. Új Honvédségi Szemle különszáma, 1996, 76-83.

[4] Sótér Andrea: Az egészségmegörzés, egészségnevelés lehetséges módszerei a Magyar Honvédség állományában, Honvédorvos supplementum, 1999, 1: 78-79.

[5] Németh A., Szilágyi Zsuzsanna, Gachályi A.,Sótér Andrea: A drogfogyasztás epidemiológiája a Magyar Honvédségnél. Honvédorvos supplementum, 1999, 1: 78-79.

[6] Szilágyi Zsuzsanna, Németh A., Rusz Edit: „Egészségesebb Laktanyákért” projekt modell kísérlet mentálhigiénés programja. Honvédorvos, 1996, 2: 115-135.

[7] Szilágyi Zsuzsanna, Kugler Gyöngyi: Kiscsoportos módszerekkel kiképzett mentálhigiénés és drog-prevenciós szakemberhálózat hatásvizsgálati eredményei a Magyar Honvédségnél. Alkalmazott Pszichológia, 2005, 7(3): 62-87.

[8] Szilágyi Zsuzsanna: A Magyar Honvédség állományában végezhető mentálhigiénés tevékenység. Honvédorvos supplementum, 1999, 1: 64-74.

[9] Szilágyi Zsuzsanna, Németh A., Csukonyi Csilla: A magyar Honvédség állományának 2004-2007 évi szürővizsgálati eredményeire alapozott összehasonlító longitudinális vizsgálata. http://mhtt.eu/hadtudo many/2011/2011_elektronikus/2011_e_1. pdf

[10] Sótér Andrea: Az MH egészségkockázati térképe, a személyi állomány egészségmagatartásának helyőrségi különbségei. Hadmérnök, 2009, 4(3): 196-211.

[11] Army Regulation 600-63 The Army Health Promotion, 2007. http://www.au.af.mil/au/ awc/awcgate/army/r600_63.pdf

[12] Novák A., Sótér Andrea, Rázsó Zsófia, Juhász Zs.: Harc az elhízás ellen: A Honvéd Testalkati Program 1. Morfológia és metodika, Honvédségi Szemle, 2017, 3: 145.74-86.

[13] Ottawa Charter for Health Promotion. World Health Organization, Ottawa, http:// www.who.int/hpr/NPH/docs/ottawa__charter_hp.pdf, 1986. 
[14] Antonovsky, A.: Health promoting factor at work: thesence of coherence, In. Psychosocial factors at work and their relation to health. Eds. Kalimo, R.:El-Batavi, M.A., Cooper,C.L. WHO, Geneva, 153-167.

[15] Omran, A. R.: The epidemiologic transition. A theory of the population change, Milbank Memorial Found Quarterly, 1971, 49(4): 509-538. DOI: $10.2307 / 3349375$

[16] Pikó Bettina: Életmód helyett életvezetés? Egészségkockázatok a posztmodern társadalomban. Valóság, 2008, 51(5): 55-64.

[17] Ornish et al.: Intensive Lifestyle Changes for Reversal of Coronary Heart Disease, JAMA, 1998, 280: 23.

DOI: $10.1001 /$ jama.280.23.2001

[18] Healthy work place: a model for action, WHO http://apps.who.int/iris/bitstream/10665/ 44307/1/9789241599313_eng.pdf

[19] Sótér Andrea: Az egészségfejlesztési irányok meghatározása a Magyar Honvédség személyi állományának időszakos egészségügyi szűrővizsgálati eredményeinek tükrében, Doktori értekezés, Nemzeti Közszolgálati Egyetem, 2014. DOI: 10.17625/NKE.2014.006

[20] Sótér Andrea, Hornyák Beatrix, Szilágyi Zsuzsanna, Németh A.: Az egészségfejlesztés alapelvei, népegészségügyi prioritása a munkahelyi egészségfejlesztés helyzete és stratégiai kihívásai a Magyar Honvédségben. Seregszemle, 2011, 9(1): 36-58.

[21] Hornyák Beatrix et al. (szerk. Meglécz Katalin): Módszertani útmutató a Magyar Honvédség személyi állomány egészségmegörzéséhez, Magyar Honvédség Egészségügyi Központ egészségügyi főnökségi kiadványa, 2013.

[22] Major Mária Gyöngyi, Sótér Andrea: Experiences from the New Screening Procedure and the Complex Lifestyle Programme of the Hungarian Army's Military Health Centre (társszerző Major Mária Gyöngyi) http://193.224.76.4/download/konyvtar/digitgy/publikacio/Major03.pdf

[23] Hornyák Beatrix, Sótér Andrea: Stresszkezelő tréning hatékonysága a Magyar Honvédségben, Honvédorvos, 2015, 67(1-2): 60-69.

\section{Lt.Col. Andrea Sótér PhD}

\section{The development of the system} of workplace health promotion activities, practice in the Hungarian Defence Forces

The challenge of NATO integration and the challenge of a capability based contracted force requires the development of a health promotion and preventive policy that can promote the development and protection of the highest level of physical and mental health of human resources. The article provides an overview of milestones in the health promotion activity of the HDF, through its regulatory and theoretical framework, to the presentations of our prevention programs. Following this review, I present the specificities of the health promotion activities carried out by law enforcement agencies, taking into account current challenges and future goals.

Key-words: workplace health promotion, prevention programs, Hungarian Defence Forces

Dr. Sótér Andrea alez., $P h D$ 1134 Budapest, Róbert Károly krt. 44. 